\title{
Art Education Need of Adults and Contribution of Art Education to Their Personalities
}

\begin{abstract}
Asuman Aypek Arslan
Gazi Üniversity, Ankara, Turkey

Education is a mental effort that an individual performs alone or in a group for the purpose of perceiving the surrounding, understanding, and putting a meaning on it. In this sense, it would be a reasonable idea that an individual should benefit from art education in order to have a complete education, since art is not just creating an aesthetic object or being aware of staying against an aesthetic object. Art means that it occurs in every stage, in every action, in all attitudes and behaviors of human being realized in an aesthetic concern without thinking. When the individuals having an art education in primary and secondary education start their education in a higher education program in a faculty or department other than art education, art education loses its continuity. However, art education should be continuous and it is of importance in terms of its contribution to this continuity since the studies of art education for the adults out of formal education would support it. The purpose of the current study was to determine the needs of adults and also the support that would be obtained from any kind of educational activities for art education, and to propose some recommendations in this sense.
\end{abstract}

Keywords: Art education, education, adult education

\section{Introduction}

Having been taken into consideration throughout the history of humanity, regarded and commented differently depending on people, art grows as an organism and surrounds all of what is known and unknown as a renewed phenomenon. It shapes cultures with the power of interpretation, expression, affecting, intuition, and pleasure and guides lives hence history. Art has been shaped and carried on in different forms in its way under the effect of a great many artists, theoreticians, thinkers, philosophers, social events and wars. Art has changed with the perception and comment of languages and thinkers and differed in time, in that way it has developed in the plane of this changeability. By its dynamics inside, art has created its basis that forms its own objectives without being mandated by any external objectives. In other words, art is a phenomenon having peculiar characteristics.

It is known that art penetrates into vital phenomena regarding human being from different perspectives. In this sense, it is likely to say that art has an impact on human beings indirectly and sometimes directly. Therefore, the functionality of art could be investigated from various points of views. As for educational perspective, art supports the development man and the community he lives in. It is known that art has objectives of teaching and training other than those of aesthetics (Balamir, 1999).

Asuman Aypek Arslan, Ph.D., Department of Applied Arts, Faculty of Vocational Education, Gazi Üniversity. 
Art is a phenomenon corresponding to the motivations of knowing, learning, and creating. In this context, the utilitarianism of art has always been regarded as a whole with the development and improvement adventure of man throughout the history of humanity, in line with the inevitability of art's functionality. This unity would be in a way that humanity not having lost its importance seeing and hearing would make it realized. Schiller (1965) defines it as "it is nothing but a manner or ability in vain unless an individual looks and hear" (pp. 142-145).

The fact that problems could be solved with the awareness of art would be understood following the complex and successive interaction of art. So, there would be a progress in social problems. In order to achieve this enlightenment, it is necessary that societies should have an education synthesized with art. In that way, there will be so called chain interaction, and a free, peaceful, cultural, and sensible process of civilization would be initiated. The idea that many people do not have a skill and it is an innate feature is so common. As must be known, this is not what is expected from people. The fact that all the people living in the world can paint good pictures and play an instrument will not reach humanity to the desired level. As a result, the most reasonable thing that human being could do for the sake of the values comprising his existence, his valuable life, ideals, and humanistic phenomena is the reality for the awareness of art. Eti (1995) stated that "if we think for a moment that all the artistic and cultural assets did not exist, we would see that there is nothing left significant. I can never think humanity deprived of culture and art" (pp. 231-236). Undoubtedly, art is a significant form of perception between the world and human being. In this sense, art is necessary for man to get to know the world and change it. It is also necessary just for the magic in itself. Whatever age an individual is, whether he is in a formal or informal education, he feels a need for the art education and the positive and improving point of view it would provide.

\section{Adult Education}

In the basis of the concept of "continuing education" in education, "widespread education", and "adult education" concepts were also embedded in the educational concepts, besides the concept of "formal education". According to Çetin (1999), formal education alone cannot be beneficial in keeping up with the changes in science and technology. For that reason, adult education is regarded as an alternative approach in many developing and developed countries today. Therefore, the significance of adult education within the system of education increased. Adult education was named differently in domestic and foreign sources. These are adult education, public education, widespread education, lifelong education, and continuing education. The common point of all these concepts is the definition of educational process aiming at facilitating the lives of the people at every age and level who are out of formal education, completing their school education process in their future periods, allowing them to improve their skills and experience, to keep up with new developments and providing them with having an access to the knowledge they need (Celep, 2003; Kurt, 2000; Geray, 1978; OECD, 1977; MEB, 1990).

Among the factors that make adult education important within general education are: providing the personal education of the individual, making individuals attain the qualifications that cannot be attained in formal education or cannot be given any opportunity to attain, providing the individual with socio-cultural development, making them attain-renew vocational knowledge and skills, guiding individuals to solving personal and social problems, making individuals attain new points of views and providing social development and improvement (Celep, 2003; Kurt, 2000).

The formation of the contents of the adult education is determined in a different way from that of formal 
education. As in formal education, the process of education is not placed on a standard and a certain period of education is not determined. The basic reason for this is that the needs and characteristics of adults who are the target group of education. Therefore, the educational activities targeting adults are planned depending on the personal, vocational, social, and cultural needs of individuals.

In order that educational activities aiming at adults are efficient and successful, it must be realized through certain principles. These principles are: continuity, forming a basis, structural flexibility, functionality, serving for society, planning a coordinating, priority among subjects, voluntariness, wishes and needs (Celep, 2003; Gedikoğlu, 1991; Kurt, 2000).

\section{Art Education}

Keeping up with the limitless and rapid changeability, infinite wishes and expectations of our age require a multi-directional, multi-dimensional, and democratic thinking. Whether it is a formal or informal education, whether it is an education with a program or without a program, art should be involved in every kind of education in every stage sometimes as an objective, sometimes as a means but always within education (Erinç, 1985).

A modern man cannot be brought up without art education. Art education has been underestimated with the idea that art is a task of competence. Art could be a task of competence in a narrow sense, however, the purpose of art education is to awake an interest at individual and make him love art. Every person can learn everything even though it is in different periods. It is unlikely for a person to reach to an intellectual level with only raw and concrete knowledge. A person without a taste of art is closed to human and community. He would bear big lacking and coarseness in his personality. His interests, behaviors and skills are limited and dull (Apaydın, 1992).

With its broadest meaning, art education, which has an indispensable place and importance in the training of modern man, should be designed in a way to make the place and importance experienced and adopted to those who are growing or grown up. Through certain programs, it should contain a process of education aiming at introducing the artistic creation fact with some practical works that will make people attain skills in various kinds and branches by showing the types of fine arts, historical development, the power of expression and those fine arts is one of the basic needs with examples.

Modern man, having an objective of maintaining a healthy, compatible, and satisfying life, is in a necessity of living in best way and improving himself, benefitting from all of the opportunities required for it, using his skills and potential powers by activating them, developing himself and exceeding it gradually (Gültekin, 1991). In order that a modern person could meet these needs, it is necessary that he looks for what is true, beneficial and useful and also free and beautiful beyond daily life knowledge, giving an effort in this sense. In order to call a person as fully trained, he needs to be trained as a person ready to improve his knowledge and skills with multi-directional, developed aesthetic and practical standards of judgment. The difference between a trained person and a person just educated mentally is observed in the fact that he is improved not only in all his competence but also in his visual and artistic competence (Gülerman, Kırl1, \& Özcan, 1991).

When it comes to art education or in its broadest sense to art-culture education, what is meant is the education at every age. Unfortunately, students of modern day are able to achieve the knowledge and aesthetic values with regard to art that modern individuals should get in their early ages only in the last stage of their teaching - learning lives and in a very limited period of time. As for the fine arts course that university students 
take within the content of "common compulsory course", the acquisitions obtained through this course that is taught in a very limited time are also limited. It is almost impossible to see courses regarding art in secondary education in terms of the programs of educational systems in Turkey. Aiming at improving the knowledge, aesthetic values, and power of judgment of individual, art education will take its place in lifelong learning and so there will be an opportunity in training modern generations relying on his future in line with "reader's fulfilment of task" (Özsoy, 2007). In order to produce solutions and find out the most successful approaches and best tools for these problems, educators have to enterprise for concrete researches and try modern approaches.

The task of parents, scientists, and administrators in making a person out of "an ordinary one" should be preparing an environment to teach the youth and new generations to feel an aesthetic concern and live this concern inside them. In other words, it is necessary to put them into an opportunity of education where they can see the options, into an environmental arrangement where they could test these options instead of making them based on conservative and static ideas (Erinç, 1985).

\section{The Need of Adults for Art Education}

It is clear that scientific processes are an indispensable reality of its unity with art education with the fact that it has high values in every walk of human life. In this context, it is inevitable to find out new educational methods in line with objectives of all the departments of our educational system, in particular, those of higher education institutions. It is essential that the objectives within this perspective should methodically have equipment that would be able to train individuals having an aesthetic taste, making other candidates get to know each other in a good way, raising their self-esteem, tolerable, having a strong ability to empathize, and being able to creative in every field of life. The adult individuals having trained through formal or informal education who are expected to have these qualities would be able to increase our country to the level of contemporary civilization as an efficient and active individual with their social roles. An adult having an art education would particularly be an individual having a commonsense and a mental sensitivity with an improved aesthetic taste with all his acquisitions in art education, and in this way they would be able to transfer their acquisitions into their lives and professional fields.

Catching the modern level of civilization will be possible with the development of creative thinking. In order to develop creative thinking in both general and artistic sense, art education should be regarded as a field that should be given starting from the preschool period, with basic, secondary, higher education level and go on with post-occupation with the process of business. In this sense, art education should not be considered as a complementary course for other courses, but as a compulsory field that should be taught because of its subjective structure. According to Yetkin (1968), if scientific method deals with one side of human formation, the other side should be dealt with art education; since human being does not only have a mind and intelligence, but he also has feelings. We cannot ignore our senses and feelings that enable us to evaluate the quality of the experience that we acquire throughout our life. A realistic education depends on the inseparable cooperation between science and art (Ayaydın, 2009). Thanks to art education, the thinking system of individual, his way of evaluating events, the attitudes towards himself and his surrounding, his aesthetic sense and his point of views to art products will change and develop. Art education should be constant within the content of lifelong learning. It is clear that the art education in formal education is insufficient. From this point of view, the individual is isolated in terms of art education and the process of his education is hindered. In this context, it is also a reality that art which has 
necessary equipment to become a complete person will be meaningful with art education. Therefore, the programs and the quality of art education in the primary and secondary education should be reviewed and prepared in a more detailed way for adult individuals in higher education which is the upper stage and in later period in the name of widespread education. Art has a function of clearing the uncertainty and arranging mental disorders. Art is primarily a dimension of human mind, then comes its being a professional activity (San, 2004).

Art is an outcome of a discipline. The discipline is able to use the potential energy for the benefit of human being. The tendencies in human being can be controlled by art and so are used in a certain direction. Under normal conditions, it is likely to say that there is no man closet to art. Perhaps, there is a man whose aptitude to art is not discovered or determined. Art is a tool used to discover human being himself and his skills. Therefore, the person who realize and use this discovery is happier and alive (Wolff, 2000). He has at least the taste of being beneficial concerning discovering and realizing art inside him. There is a clear difference between the person touched by art and the one deprived of art. An adult dealing with any kind of art will have the traces of that art in his physical world as well. Depending on the qualities of that art he has, he will have an ill-tempered, nervous, strained or a quiet, comfortable and inert mood. Then, everybody should have an art regardless of his conditions, status, age or educational level. There should be no one without art. It is of significant for both the internal consistency of that person and for the people around him. In particular, the interest of adults having a hard time in art will help them to get over these hard times with little trouble. Art is also a factor that has a positive impact on human psychology. An adult proving himself in the field of art has surely an emotional balance.

\section{Conclusion}

When it comes to training creative, futuristic, and intellectual individuals needed by our age, who are aware of benefitting from the innovations of improving informatics technologies, with improved thinking potentials, the importance of art and culture education will be well perceived. In this sense, adults should be led to understand the common culture and be made to think critically by empowering their skills of asking questions, facing, judging, and alternative creativity. The need of modern man for art education definitely requires spending more time on art education within general education, since it is an obligation for countries to train creative people who are needed by creative communities. It would be beneficial to include art education courses which are pedagogically qualified enough in all teaching programs of departments at faculties of higher education institutions in order that university students could make an analysis by their perceptions through the awareness of age and art, and become individuals who can feel respect for universal values, share different initiatives, discover inner dynamics and improve them as a person full of love. Besides that, art education should be given to adult individuals who have never had a higher education through the activities to be provided within their working surroundings. Artistic activities should be enriched with such things as guiding working adults to artistic activities and encouraging them, arranging exhibitions, seminars, conferences and courses dealing with art open to people from every walk of life and encouraging them, making the cultural activities and art education in institutions increased, making art educations in museums and galleries included in their activities in order that people could benefit from them. The purpose here is to make adult individuals become sensitive people to their types of arts in their country as a consumer of art with a higher level of taste, regardless of their branches and fields. These people who have their own occupations should be supported to enrich their lives by painting, 
dealing with music and performing in theatric activities in their free times, so making their lives meaningful. The current age is an era focusing on nationalization, paying attention to being scientific and technological. It is no use to ignore and avoid it. Therefore, art education should guide all modern individuals to whom it contacts, as a child, adolescent, young, or adult, to art realities in the universal life extensively by equipping them with intensive art activities through modern science and methods without alienating them to their culture. The adult having an art education would become a more right-minded individual with mental sensitivity having an improved taste of art with his acquisitions in art and in that way they would be able to use these acquisitions in their lives and professional fields.

\section{References}

Apaydın, T. (1992, June). Okullarımızda sanat eğitimi (Art Education at our schools). Cumhuriyet Newspaper, p. 5.

Ayaydın, A. (2009). Sanat eğitimive görsel sanatlar öğretimi (Art education and visual arts teaching). Ankara: PegemAkademi Publishing.

Balamir, B. (1999). Sanat eğitiminde özgürlükve özgünlük (Freedom and originality at art education). Ankara: Ministry of Culture, Cultural Works.

Celep, C. (2003). Halk eğitimi (Public education). Ankara: Anı Publishing.

Çetin, Ş. (1999). The educational needs of teachers working at public education centres as an adult educator. MEB Journal, 142, 56-63.

Erinç, M. S. (1985). Yaşamı güdüleyici biretken. estetik kaygı (An active aesthetic concern motivating life). Art Papers I. H.UFFA Publishing.

Eti, E. (1995). Why art. The Symposium of Fine Arts Faculties and Educational Programs (pp. 231-236). Eskişehir: Anadolu Üniversitesi Güzel Sanatlar sempozyumu.

Gedikoğlu, Ş. (1991). Türkiye'de yaygin eğitimden çağdaş halk eğitimine (From widespread education to modern public education in Turkey). Ankara: Gül Printing House.

Geray, C. (1978). Halk eğitimi (Public education). Ankara: A.U. FESIssue No: 73.

Gülerman, A., Kırl1, Z., \& Özcan, G. (1991). The objectives and qualities of music course. University Programs FES. 1st International Congress. Ankara.

Gültekin, Ü. (1991). Marginalized modern art in our developing country, the place of art in the development of a country. 3rd National Art Symposium. Ankara.

Kurt, İ. (2000). Yetişkin eğitimi (Adult education). Ankara: Nobel Publishing, Distribution.

MEB. (1990). Regulation for widespread education institutions. Ankara: General Directorate for Apprenticeship and Widespread Education.

OECD. (1977). Learning opportunities for adults. General Report, 1, 36-41.

Özsoy, V. (2007). Görsel sanatlar eğitiminin, resim-İ̧ eğitiminin tarihselve düşünsel temelleri (Historical and intellectual bases of visual art education and drawing education). Ankara: Gündüz Training and Publishing.

San, İ. (2004). Sanatve eğitim. yaraticilik temel sanat kuramlari sanat eleştirisi yaklaşimları (Art and education, basic art theories creativity, art criticism approaches). Ankara: Ütopya Printing House.

Schiller. F. (1965). İnsanın estetik eğitimi üzerine bir dizi mektup (A series of letter over the aesthetic education of human being). (M. MelahatÖzgü, Trans.). İstanbul: Eğitim Printing House.

Wolff, J. (2000). Sanatın toplumsal üretimi (Social production of art). (A. Demir, Trans.). İstanbul: Özne Publishing.

Yetkin, S. K. (1968). Güzel sanatlarin eğitimdeki yeri (The place of fine arts at education). Journal of Faculty of Education, 1 , 78-83. 